\title{
Drogas, conflito e os EUA. A Colômbia no início do século
}

\author{
LEÓN VALENCIA
}

A EXTRADIÇÃo PARA os Estados Unidos de Gilberto Rodríguez Orejuela, um dos maiores narcotraficantes da Colômbia, nos primeiros dias de dezembro de 2004, fez com que todos os colombianos se lembrassem de uma época, no fim dos anos de 1980 e no princípio da década de 1990, quando o país foi estremecido por uma onda do terrorismo praticado pelos narcotraficantes.

Gilberto Rodríguez Orejuela, que é sem dúvida o segundo mais poderoso narcotraficante já produzido pelo país, depois de Pablo Escobar Gaviria, recordava em entrevista dada a uma emissora local, antes de ser embarcado para os Estados Unidos, que em uma campanha que chamou de "Plano Pistola" Escobar tinha mandado assassinar, um por um, quatrocentos policiais na cidade de $\mathrm{Me}$ delín ${ }^{1}$. Comentava Orejuela que essa ação, levada a cabo por um único homem, empregando assassinos de aluguel, podia perfeitamente ser incluída na primeira linha das ações terroristas mundiais.

Em seguida, Rodríguez Orejuela contava que tinha sido o artífice da morte de Pablo Escobar, que durante vários meses o havia seguido e que tinha em seu poder gravações de centenas de horas de conversas de Escobar; que quando viu que a sua presa não tinha escapatória entregou-as às autoridades. Não é difícil assim admitir que Rodríguez Orejuela não era menos ousado e perigoso do que Escobar.

No choque entre Escobar e o Estado, e entre Escobar - que comandava o Cartel de Medelín - e os Rodríguez Orejuela - que chefiavam o Cartel de Cali -, milhares de pessoas morreram. Em algumas cidades, os edifícios explodiam em pedaços com a detonação das poderosas bombas dos narcotraficantes, os aviões eram espaços de medo. Não há neste mundo quem não se assombre ao saber que quatro candidatos presidenciais, de diferentes tendências políticas, sucumbiram nesse choque. A sociedade foi toda assediada.

Nessa época foram estabelecidos acordos de paz com cinco grupos guerrilheiros que tinham conseguido um grande impacto no país, ao longo de mais de vinte anos de atividade; uma nova Constituição foi promulgada, para substituir uma Carta Constitucional que tinha mais de cem anos, e a economia recebeu um impulso com a promoção de uma primeira abertura para o mercado mundial. Tudo isso, porém, foi engolido pela grande ofensiva terrorista do narcotráfico; tudo foi apagado pela escalada de morte e destruição promovida pelos cartéis das drogas. A tragédia colocou na sombra acontecimentos que em sociedades tranqüilas teriam significado uma mudança tão radical como inesquecível na vida nacional. 
A sociedade colombiana percebeu, então, um fenômeno que havia crescido silenciosamente nas suas entranhas, e começou a se dar conta também de que o cultivo, o processamento e o tráfico de drogas já tinha criado raízes profundas na vida nacional, gerando o negócio mais lucrativo e que mais dinheiro movimentava no país. Tinha comprometido milhões de pessoas, introduzindo-se na política tradicional e nas guerrilhas, gerando grupos armados para proteger o negócio ilegal.

No fim dos anos de 1980 a Colômbia se convertera em um caso único no mundo. No seu território eram cultivadas a coca, a maconha e a papoula. Tudo começara nos anos de 1970, com o plantio da maconha, mas em seguida foi introduzido o cultivo da coca, deslocando a Bolívia e o Peru. Audaciosamente, logo se começou a cultivar a papoula, que tinha sido um monopólio asiático. O Relatório do UNDCP para 2004 registra 4,1 mil hectares cultivados de papoula, mas pesquisadores como Uribe e Thoumi questionam esses dados, utilizando várias fontes e trabalhos de campo. Para 1996, quando os números do Departamento de Estado norte-americano indicavam um pouco mais de seis mil hectares plantados com papoula, esses pesquisadores calculavam essa extensão em 20,4 mil hectares. Há mais concordância no que respeita à maconha: estima-se que há vários anos a área semeada é da ordem de cinco a seis mil hectares.

Mas o cultivo da folha de coca, o processamento e o tráfico da cocaína foram as atividades mais importantes no mundo das drogas ilegais. $\mathrm{O}$ ano 2000 foi o ponto mais alto dessa atividade, quando a extensão do cultivo atingiu 163 mil hectares, e a remessa de cocaína para o exterior chegou a setecentas toneladas anuais $^{2}$. Assim, a Colômbia controlava cerca de $60 \%$ desse negócio no mundo. Com o quilo de cocaína valendo em média no atacado trinta mil dólares no mercado internacional, essas transações ultrapassavam os vinte bilhões de dólares.

\begin{tabular}{l|c|c|c|c|c|c|c|c}
\hline \multicolumn{7}{c}{ Cultivo de coca na região Andina 1996-2003 (hectares) } \\
\hline Pais & 1996 & 1997 & 1998 & 1999 & 2000 & 2001 & 2002 & 2003 \\
\hline Bolivia & 48,100 & 45,800 & 38,000 & 21,800 & 14,600 & 19,900 & 24,400 & 26,600 \\
\hline Peru & 94,400 & 68,800 & 51,000 & 38,700 & 43,400 & 46,200 & 46,700 & 44,200 \\
\hline Colombia & 67,200 & 79,400 & 101,800 & 160,10 & 163,30 & 144,80 & 102,10 & 86,300 \\
\hline Total & 209,700 & 194,000 & 190,800 & 220,600 & 221,300 & 210,900 & 173,200 & 154,100 \\
\hline & $\begin{array}{l}\text { Departamento de Estado } \\
\text { EEUU }\end{array}$ & & \multicolumn{7}{l}{$\begin{array}{l}\text { Sistema Nacional de Monitoreo } \\
\text { soportado por UNODC }\end{array}$} \\
\hline
\end{tabular}

Fonte: Colombia Monitoreo de Cultivos de Coca, Unodc, jun. 2004. 
Gráfico l - Relação entre cultivos ilícitos e grupos armados ilegais



No entanto, a característica mais especial não é esta confluência de cultivos de drogas psicoativas com grande demanda no mundo; o mais dolorosamente especial é que o narcotráfico veio potencializar outros fenômenos presentes na vida colombiana: a violência das guerrilhas e dos paramilitares, o clientelismo e a corrupção, a cultura do jeito e a desinstitucionalização do país. No princípio, embora houvesse vasos comunicantes, esses fenômenos se mantinham separados, mas não tardaram a se juntar.

No ano de 1987, um grupo de renomados especialistas convocados pelo Ministro de Gobierno preparou um relatório sobre a violência, deixando bem claro que era possível distinguir três tipos: a dos delinqüentes comuns, a do narcotráfico e a de motivação política, associada às guerrilhas e a grupos paramilitares $^{3}$. Esses tipos de violência ainda tinham dinâmicas separadas, mas ficou evidente que, no começo da década de 1990, eles começaram a se articular. Assim, as guerrilhas, especialmente as Farc, passaram a cobrar impostos dos camponeses, a controlar diretamente plantações e a processar a folha de coca. Os narcotraficantes puseram-se a criar grupos paramilitares para defender o seu negócio ilegal, juntando-se com os pecuaristas e outros empresários que se voltavam para essas práticas. Uns e outros, guerrilheiros e paramilitares, começaram também a subordinar-se a atividades da delinqüência comum. No caso dos paramilitares isso ficou mais evidente: em Medelín e em outras cidades eles puseram a seu serviço quadrilhas de delinqüentes que há algum tempo já operavam ali, mas as Farc também se apoiaram em grupos desse tipo, sobretudo para cometer seqüestros em todo o país. A associação de narcotraficantes com guerrilheiros ou paramilitares apossou-se do maior espaço criminoso, embora subsistissem pequenos cartéis, dotados de uma certa autonomia: fala-se hoje em oitenta grupos desse tipo. 


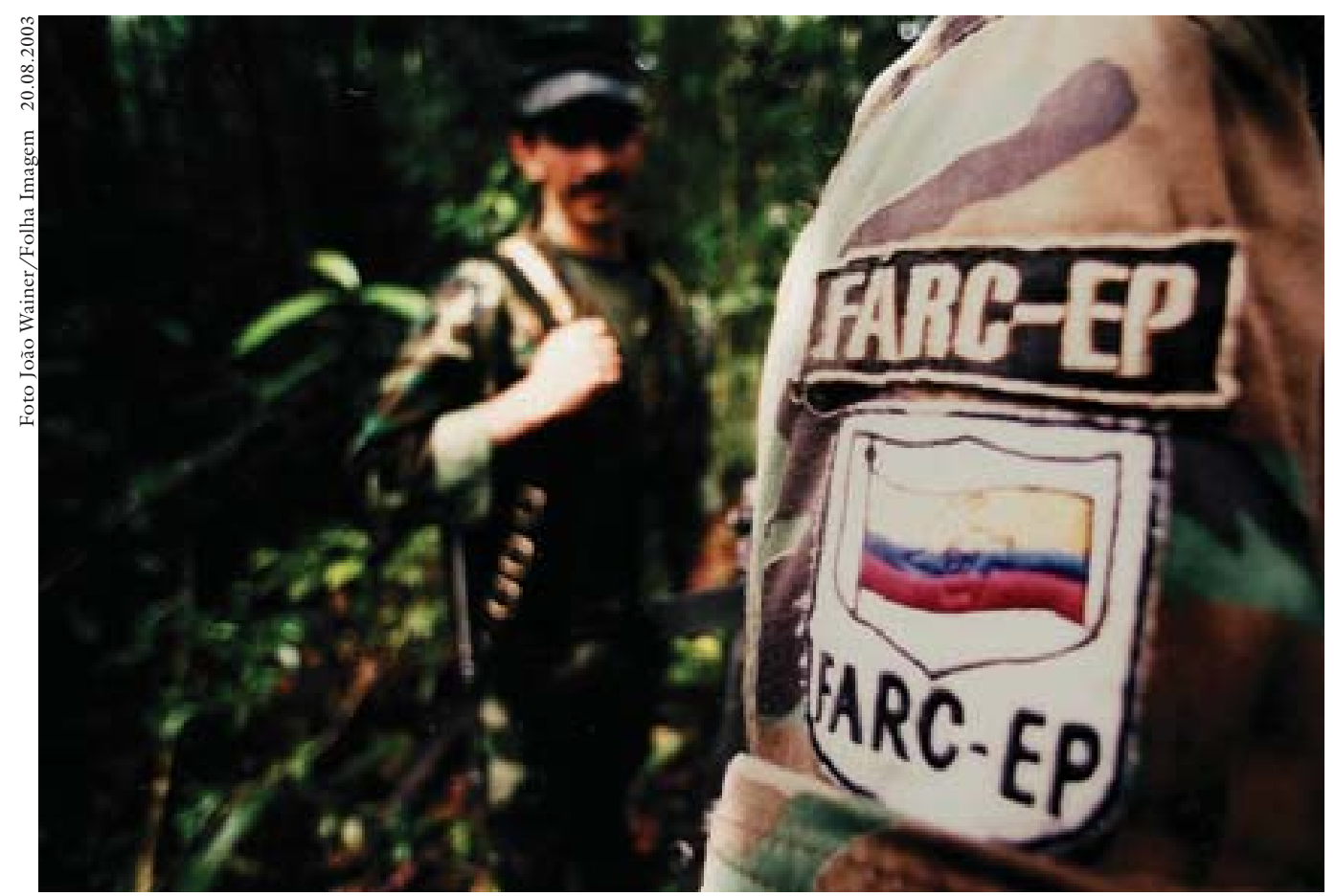

Detalhe do brasão das Farc (Forças Armadas Revolucionárias da Colômbia) no uniforme de soldado da milicia que monta guarda na selva colombiana na fronteira com o Equador.

A guerra mudou de aparência. Com a articulação da violência do narcotráfico e da delinqüência comum com a violência política, o conflito armado deu um grande salto, emitindo um claro sinal de que o Estado podia entrar em colapso. Converteu-se assim em um fator de desestabilização para toda a região andina e começou a preocupar de modo especial os Estados Unidos.

Por outro lado, a política tradicional também mudou. Em 1994, estourou em Bogotá o maior escândalo político do século: Andrés Pastrana Arango, candidato presidencial derrotado, revelou ao público gravações que comprometiam o candidato vitorioso, Ernesto Samper Pizano, com o recebimento de dinheiro do narcotráfico para financiar a sua campanha eleitoral. Com um esforço titânico, Samper Pizano conseguiu ser absolvido pela Câmara de Representantes, à qual coube o julgamento político do caso, demonstrando que ignorava as tratativas entre os agentes da sua campanha e os narcotraficantes, embora tivesse ficado provado plenamente que os responsáveis por esse financiamento tinham recebido aquelas contribuições. Esse processo evidenciou uma realidade que afetava toda a política colombiana: em não menos de vinte anos uma parte importante do financiamento dos políticos provinha de recursos do narcotráfico, o que foi confirmado por Gilberto Rodríguez Orejuela na entrevista que citamos, ao declarar tranqüilamente: "Durante vinte anos fiz contribuições". Mas a sua participação era apenas uma parte do problema. Com o escândalo se soube que por muito tempo as principais campanhas locais e nacionais eram apoiadas pelos dólares de todos os cartéis da droga. 
Também no campo da política o terreno estava bem preparado para receber a influência do narcotráfico. A política colombiana se tinha sustentado, ao longo do século, no clientelismo, na compra e venda de votos, e o dinheiro do narcotráfico levara essa prática ao seu apogeu.

O governo dos Estados Unidos reagiu a essas mudanças drásticas da vida colombiana fazendo uma variação fundamental na sua política com relação à Colômbia. Há muitos anos a estratégia que seguira diante do conflito interno e do fenômeno do narcotráfico baseava-se na contenção. Em livro recente, um pesquisador americano, Nasih Richani, conseguiu demonstrar que essa atitude estava sustentada por uma visão racional do Departamento de Estado. Durante muitos anos, o State Department adotou a idéia de que as guerrilhas colombianas não representavam uma ameaça contundente. Richani cita relatórios desclassificados do Departamento segundo os quais, por esse motivo, "o objetivo viável, tanto para o governo americano como para o colombiano, é a contenção em lugar da eliminação. A combinação de recursos colombianos e americanos visa a alcançar esse objetivo, enquanto a eliminação exigiria enormes recursos, que seriam melhor utilizados para outros fins" ${ }^{4}$. O modo de enfrentar o narcotráfico durante a época em que ele não estava associado estreitamente ao conflito armado consistia em "controlar" e "limitar" o fluxo de drogas para o seu território.

A mudança de estratégia ficou patenteada com a aprovação do "Plano Colômbia", com o qual os Estados Unidos substituíram o objetivo da "contenção" pela "eliminação", e para isso multiplicaram os recursos disponíveis e deram um salto na sua participação no conflito colombiano. Sua cooperação militar foi ampliada para 700 milhões de dólares por ano, em média; em quatro anos o número dos funcionários lotados na Embaixada em Bogotá aumentou de quatrocentos para dois mil.

\section{O problema}

Constitui um problema para o mundo os treze milhões de pessoas (mais da metade nos Estados Unidos) que, segundo o Escritório de Crime e de Drogas das Nações Unidas - UNDCP - são viciadas em cocaína. Para os Estados Unidos, são um problema os cinqüenta mil cidadãos que morrem todo ano no seu território devido ao tráfico de drogas; e esse país precisa preocupar-se com o fato de que $80 \%$ da cocaína e $50 \%$ da heroína que ingressa no seu território provêm da região andina. Mas esta é apenas uma parte da tragédia. Para países como Colômbia, Peru e Bolívia constitui também um problema os milhões de camponeses que se vêem obrigados a cultivar a folha de coca, assim como a guerra contra a droga que se desenrola no seu território e as conseqüências dessa guerra: mortes, contaminação ambiental, deslocamentos, fome e instabilidade política e social. Assim, o problema é de todos.

Quando se diz que o auge da área cultivada na Colômbia com folhas de coca foi de 163 mil hectares no ano 2000, e que a área cultivada em todo o mundo nunca ultrapassou trezentos mil hectares; e quando se afirma que o supri- 
mento médio de cocaína no mercado mundial, nos últimos quinze anos, foi de 650 mil kg, poder-se-ia concluir que, na verdade, o problema não é tão grande. No entanto, grandes são as repercussões desse consumo e desse comércio.

Alguns analistas assinalam que, embora os problemas de saúde dos consumidores e a apreensão que gera a cocaína nos seus viciados, com repercussões no trabalho e nas relações familiares e sociais, constituem um problema importante. O conflito é agravado com a dura estigmatização a que têm sido submetidos o cultivo, o tráfico e o consumo de drogas, como também a condição de ilegalidade em que se desenvolvem essas atividades. A estigmatização e a proibição geram as conseqüências mais variadas. A primeira delas é a perseguição e a marginalização da sociedade, que afeta milhares de pessoas. A segunda é o encarecimento inusitado do negócio e a alta rentabilidade que traz para alguns dos seus agentes. A terceira é a gestação de formas ilegais e armadas de proteção. A quarta é a corrupção que gera no Estado, nos partidos políticos e até mesmo na empresa privada. Mas sem dúvida o principal problema que alimenta o tráfico de drogas na Colômbia é o conflito armado interno.

Gráfico 2 - Cultivo de coca na Colômbia 1991-2003

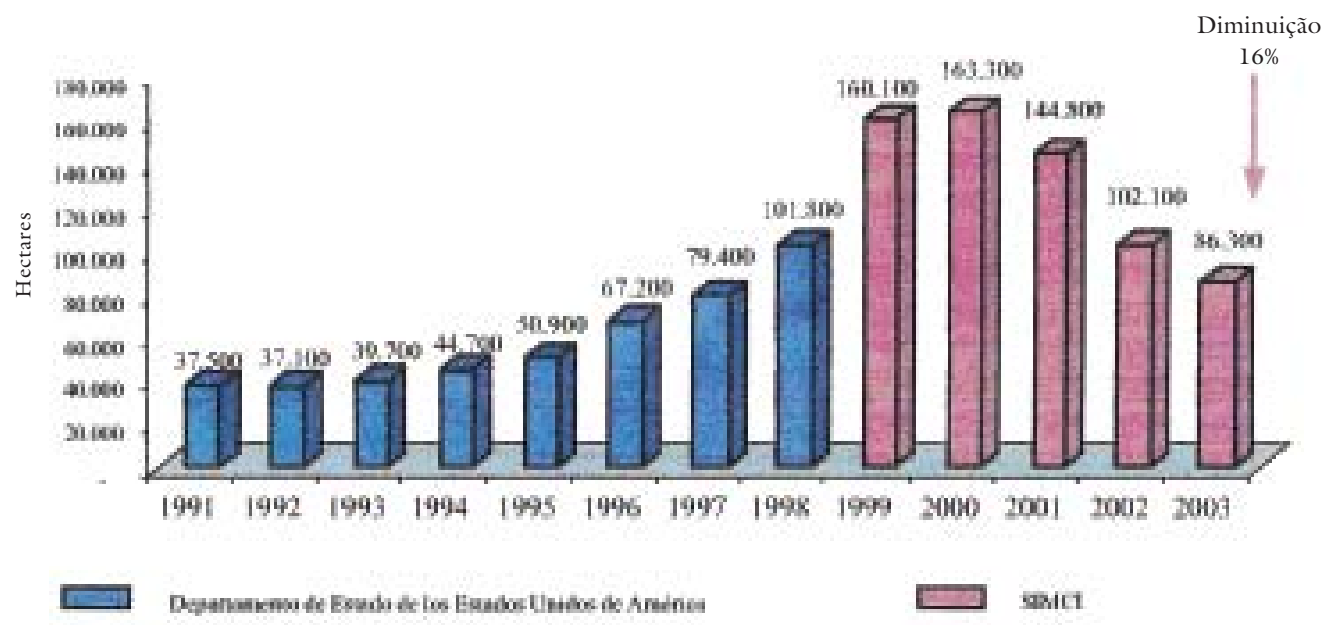

Nota: Os estimados para 1999 e anos subseqüentes provém de SIMCI. Dado à mudança de metodologia, as cifras a partir de 1999 não podem ser comparadas diretamente com dados de anos anteriores (baseados nos censos do governo dos EUA).

Fonte: Colômbia, Monitoreo de Cultivos de Coca, UNODC, jun. 2004.

$\mathrm{Na}$ Colômbia, essas conseqüências têm características dramáticas. Em uma nota do seu livro, o pesquisador Richani diz:

Se somarmos os produtores de coca, os cultivadores de papoula e maconha e os negociantes dos insumos necessários para a transformação da coca em cocaína, o número se aproximará de um milhão de agricultores, pequenos camponeses e trabalhadores agrícolas que dependem total ou parcialmente desses cultivos ilegais ${ }^{5}$. 




Mapa 1 - Cultivos de coca na Colômbia em 2003

O cálculo é feito citando vários pesquisadores colombianos que procuraram identificar as repercussões sociais dessa atividade. O número das pessoas envolvidas aumenta se contarmos as famílias, e aumenta ainda mais se pensarmos nos milhares de indivíduos que vendem a droga ou trabalham para os narcotraficantes. Pois bem: essa parte da sociedade, nada inferior a quatro milhões e meio de pessoas no país, ou seja, 10\% da população, vê no Estado um inimigo, e foge dele, mas quando pode também o enfrenta, unindo-se com outros ilegais em busca de proteção.

O caráter ilegal do cultivo, processamento e tráfico da cocaína é, sem dúvida, o que multiplica o custo da droga e gera uma alta rentabilidade e o enriquecimento fácil dos exportadores. Como diz Antonio Caballero, intelectual co- 
lombiano, "se não fosse a proibição a cocaína seria um negócio com o mesmo rendimento do café" 6 . O risco que correm a liberdade e a vida nesse trabalho ilegal é cobrado com um rápido crescimento da riqueza. Os grandes narcotraficantes colombianos chegaram a fazer parte do clube das pessoas mais ricas do mundo, e ainda hoje exibem fortunas que causam inveja aos empresários legais de grande tradição. Mesmo para os pequenos plantadores, que recebem uma parte mínima de todo o dinheiro da droga, é mais rentável cultivar a coca do que outros produtos. Em uma reportagem impressionante feita no coração da selva colombiana, o jornalista Carlos Villalón, do National Geographic, descreve assim a situação dos camponeses: "Por uma boa qualidade, o traficante paga mais ou menos mil dólares por um quilo de pasta de coca. Depois de comprar provisões e de pagar os seus trabalhadores, o agricultor pode tirar para si uns 325 dólares". O que é impossível com produtos legais.

Esse negócio ilegal que nos seus melhores momentos alcançou um valor maior do que o resto das exportações colombianas tem razão de atrair tantos “empresários" e de gerar toda uma trama de proteções e imensas resistências. Ainda hoje, no fim de 2004, quando o UNDCP afirma que a remessa de cocaína para o exterior caiu para 450 toneladas em conseqüência do "Plano Colômbia", se tomarmos como preço médio por atacado os trinta mil dólares, teríamos 13,5 bilhões de dólares como valor aproximado dos negócios, enquanto todas as exportações legais da Colômbia são da ordem de 11,5 bilhões no mesmo período de um ano.

Obviamente, nem todo esse dinheiro ingressa no país. Nos últimos anos o Departamento de Estado norte-americano tem falado em um retorno ao território colombiano de cinco bilhões de dólares. Esses cálculos são incertos, mas há algo certo que indica a grande influência que esse negócio tem tido na economia do país. Entre 1981 e 1990, o aumento acumulado do Produto Interno Bruto na América Latina foi de 12,4\%, enquanto na Colômbia foi de 43,6\% ${ }^{7}$. Essa inconsistência entre um país e toda a sua região, compartilhando as mesmas dificuldades, só se pode atribuir a fenômenos extraordinários como o tráfico de drogas.

“Todo negócio ilegal gera uma proteção ilegal, por isso é impensável uma completa extinção dos paramilitares à margem de um desaparecimento do lucrativo tráfico de drogas", diz o empresário colombiano Ricardo Avellaneda, que participou da primeira comissão exploratória nomeada pelo governo para as negociações com as autodefesas Unidas de Colômbia ${ }^{8}$. Esta afirmativa de uma pessoa estudiosa do tráfico de estupefacientes no conflito armado deixa entrever a conexão íntima que existe entre o fenômeno paramilitar e o negócio das drogas. Em todo caso, a afirmativa foi bastante confirmada no começo das negociações com os paramilitares, em meados de 2004. Dos dez chefes nomeados pelos paramilitares para dirigir a negociação com o governo, seis estavam incluídos na lista de grandes narcotraficantes dos Estados Unidos. 
No entanto, a justificativa imaginária que os paramilitares tinham conseguido forjar na opinião pública colombiana, nos últimos anos, era a de que representavam uma resposta política armada aos atropelos da guerrilha. $\mathrm{O}$ esforço feito para implantar essa idéia na sociedade colombiana durou vários anos, mas teve um momento especialmente importante: o dia 18 de abril de 1997, quando os paramilitares se reuniram para fundar as Autodefesas Unidas da Colômbia. Participaram dessa reunião as Autodefesas de Córdoba e Urabá, dos llanos orientais, de Puerto Boyaca e de Ramón Isaza, que operavam no médio rio Magdalena. $\mathrm{Na}$ ata da reunião podia-se ler, no terceiro ponto: "Definir as Autodefesas Unidas da Colômbia como um movimento político-militar de caráter subversivo, no exercício do direito de legítima defesa, que exige transformações do Estado, mas não atenta contra ele" ${ }^{\text {. }}$.

Até mesmo os estudiosos da realidade nacional esqueceram que um grupo emblemático dos paramilitares, surgido na década de 1980, o chamado MAS, “Morte aos Seqüestradores", formou-se para resgatar Marta Nieves Ochoa, pertencente a uma família vinculada ao Cartel de Medelín. Embora esse seqüestro fosse perpetrado pelo Movimento 19 de Abril (M19), dificilmente se pode atribuir à reação dos Ochoa motivação política. Tratava-se de uma ação orientada para proteger o dinheiro acumulado em um negócio ilegal, de proteger uma família de narcotraficantes. $\mathrm{O}$ mesmo se pode dizer com respeito à reação da família Castaño Gil ao seqüestro e morte de seu chefe. As Farc seqüestraram esse camponês, que já tinha riquezas provenientes das atividades ilícitas de Fidel Castaño, um dos filhos mais velhos. O mito de que os Castaño se viram movidos pela injustiça das Farc a organizar uma guerra política não corresponde inteiramente à verdade. Com efeito, os Castaño já estavam ligados a Pablo Escobar e já participavam do negócio das drogas, e começaram a enfrentar a guerrilha para defender a sua fortuna.

Pode ser tão inexato afirmar que o papel fundamental dos paramilitares tem sido liberar a Colômbia das guerrilhas e proteger a atividade lícita dos empresários do campo e da cidade como negar que, em parte, tenham também cumprido essa missão. Na formação dos paramilitares tiveram ainda um papel importante os pecuaristas do país, assim como outros empresários. De modo que, simplificando um pouco as coisas, podemos dizer agora, quando as negociações estão revelando tantos segredos, que os paramilitares foram formados para proteger um negócio ilegal, o tráfico de drogas, assim como um negócio legal, parasitário: a criação extensiva de gado, atividade que ocupa grande parte do território nacional e emprega pequenos grupos de trabalhadores em condições miseráveis.

Carlos Castaño, que por muito tempo foi a cabeça visível dos paramilitares, em uma de muitas entrevistas dadas à imprensa do país reconheceu que as Autodefesas eram financiadas com o narcotráfico em cerca de $70 \%$. É certo que os líderes do narcotráfico tiveram muito que ver com a origem dos grupos para- 
militares; é verdade, também, que uma parte importante dos recursos para a compra de armamento e para sustentar os combatentes provinha dessas atividades, mas a vinculação maciça dos narcotraficantes se deu no ano de 1999. Depois de realizada uma segunda reunião de ampliação desse agrupamento, em 16 de maio de 1998, na qual se vincularam a ele outros grupos dispersos de paramilitares, Carlos Castaño passou a estender sua influência por todo o país, adotando uma atitude claramente ofensiva. Foram criadas então estruturas como o Bloco Central Bolívar, o Bloco Catacumbo e o Bloco Calima. As Autodefesas deram então um enorme salto. Dos seis combatentes admitidos no momento da sua formação como força nacional, em 1998, passaram a declarar que tinham treze mil em 2003, quando foram iniciadas as conversações, e que, em 2004, ao começar a desmobilização, somavam já vinte mil membros ${ }^{10}$.

O esforço de rápida expansão e o fortalecimento inusitado implicou uma inversão fabulosa. A vinculação de comandos e combatentes era feita com a oferta de salários elevados e recompensas: tratava-se de uma contratação aberta de mercenários, em grande escala. Nos dados que foram divulgados publicamente chegou-se a falar em salários mensais de 2.500 dólares para um comandante de nível médio das autodefesas. Havia também sofisticadas transações nacionais e internacionais para adquirir armamento e infra-estrutura de primeira qualidade que, conforme se viu, era composta não só por fuzis mas por peças de artilharia ligeira, frotas de helicópteros, aviões e lanchas.

Obviamente, o narcotráfico não era a única fonte de recursos das Autodefesas. Elas contavam igualmente com o roubo e o uso de combustíveis, o saqueio de bens do Estado e também os seqüestros, que tanto criticavam nas guerrilhas. Mas no caso das Autodefesas o narcotráfico contribuia não só para financiar a guerra como servia de principal fonte para o enriquecimento pessoal. Tanto é assim que Juan Camilo Restrepo, ex-Ministro da Fazenda e ex-candidato conservador à Presidência da República, referia-se aos chefes das Autodefesas como "senhores da guerra", devido à grande acumulação de terra e de riquezas que estavam em suas mãos ${ }^{11}$.

As Farc também não ficaram atrás na utilização de recursos provenientes do narcotráfico para financiar a guerra. Com efeito, o grande desenvolvimento das Farc, em meados dos anos de 1990, baseou-se igualmente no ingresso em larga escala de dinheiro do narcotráfico. Nessa época, as Farc duplicaram seu efetivo e formaram um verdadeiro exército guerrilheiro, que, no Sul do país, impôs dezesseis derrotas sucessivas às forças militares, entre 1996 e $1998^{12}$, chegando ao fim do século com não menos de vinte mil combatentes. Atualmente, as Farc participam de vários elos da cadeia. Pouco a pouco passaram a cobrar impostos, a processar e a refinar cocaína, a envolver-se no comércio das drogas, mas dão preferência à cobrança de impostos, com taxas significativas. Carlos Villalón, o jornalista que já citamos, publicou no National Geographic de julho de 2004 uma fotografia de camponeses em uma loja entregando pasta de coca a um inter- 
mediário, que a levaria a um centro de produção de cocaína. A foto tem os seguintes dizeres: "Um traficante pesa as bolsas de base que os agricultores trouxeram a Santa Fé para vender, e as paga com dinheiro vivo, que tira de um saco que mantém entre as pernas. A seu lado um ajudante anota cada compra, para que as Farc possam receber seu imposto de 30\%”.

O Departamento de Planejamento Nacional da Colômbia estimava que em 1996 a receita da guerrilha era de \$ 1.155.900.000.000 de pesos colombianos, ou seja, 1,54\% do PIB daquele ano - mais de quinhentos milhões de dólares. De seu lado, alguns analistas se atrevem a dizer que no caso das Farc, $48 \%$ da sua receita provêm do tráfico de drogas, e no caso do ELN, $6 \%{ }^{13}$.

Há uma diferença entre os paramilitares e as guerrilhas. Os primeiros se enriquecem individualmente, enquanto as guerrilhas investem tudo na guerra exceto casos de corrupção nas suas fileiras. Há também uma outra diferença: não houve ainda casos devidamente documentados de tráfico de drogas para o exterior por parte das guerrilhas. Está claro que isso é facilmente explicável pelos fenômenos de decomposição que podem ocorrer, assim como pelos riscos de segurança, pois uma das principais preocupações da guerrilha é conservar suas forças. No seu livro El Império de la Droga, Francisco Thoumi, um dos mais reputados pesquisadores internacionais no campo das drogas, salienta essas diferenças, e diz: "Em meados dos anos noventa os principais grupos revolucionários colombianos dependiam financeiramente do tráfico de drogas ilícitas. Não há dúvida sobre isso; no entanto, não há evidência de que tivessem redes de comercialização internacional. Portanto, neste sentido não havia um cartel guerrilheiro" $"$.

Há dirigentes políticos que se atrevem a dizer que a corrupção é ainda mais prejudicial do que o próprio conflito armado, e na Colômbia uma parte importante da corrupção, embora não toda ela, está associada ao tráfico de drogas. O processo político e judicial desenvolvido contra a campanha política do Presidente Samper demonstrou como a corrupção do narcotráfico tinha penetrado profundamente na política colombiana. E logo se pôde ver que esse não era o único campo atingido pela corrupção. A Justiça mostrou parte das suas feridas, assim como a empresa privada. No livro que citamos, Thoumi ousa ir ainda mais longe:

O testemunho dos camponeses das regiões de cultivo envolve também as Forças Armadas no comércio ilegal. A entrega de mais de seiscentas gramas de cocaína a bordo de avião C-130 da Força Aérea Colombiana em Fort Lauderdale, na Flórida, em fins de 1998, confirma esses testemunhos.

Muitos estudiosos do tema das drogas, líderes políticos e religiosos, podem contradizer com bons argumentos a idéia de que a proibição das drogas psico-ativas é a causa de todos os males, mas o que não podem negar é que a ilegalidade e a guerra contra as drogas aumentaram enormemente o problema, em lugar de resolvê-lo. A proibição apóia-se na constatação das graves disfunções 
sociais provocadas por essas substâncias, com os seus efeitos sobre a saúde, o trabalho, as relações interpessoais. Mas a proibição também se alimenta (e de que maneira!) de um enfoque moralista. Os Estados Unidos enfatizam essa visão moralista, a partir da qual projetam duras políticas repressivas. Reprime-se os consumidores, mas concentra-se o esforço principal sobre os produtores e traficantes. A chamada "guerra contra as drogas" é, na verdade, uma batalha que se passa fora das suas fronteiras.

No mundo, e nos próprios Estados Unidos, há muitas críticas a essa visão que predomina na política norte-americana, mas a variação dessas políticas está longe. A esse respeito Thoumi observa:

É preciso registrar que nos Estados Unidos é grande o apoio social e político com que contam as suas políticas atuais, mas ele é bastante limitado entre os acadêmicos e os analistas. Um estudo recente sobre pontos de vista entre funcionários do Congresso, acadêmicos, centros de pensamento político (think tanks) e consultores de Washington verificou um consenso sobre a necessidade de mudar essas políticas e a impossibilidade de fazê-lo no curto e no médio prazo. Nesse estudo todos os entrevistados coincidiam em que nenhum político percebe ganhos associados com a promoção da mudança dessas políticas ${ }^{15}$.

\section{O plano Colômbia}

A grande ofensiva contra o cultivo, o processamento e o tráfico de drogas na Colômbia começou a ser gestada a partir de 1994, quando tiveram início as fumigações. Desde esse ano até 25 de junho de 2004, quando se celebrou o dia mundial de luta contra a droga, haviam sido fumigados 621.221 hectares de plantações de coca. Essa área tinha duplicado, passando de 44,7 mil hectares em 1994, para 86,3 mil em 2004 ${ }^{16}$.

O período mais intenso de fumigação, e também o de enfrentamento mais duro de grupos armados ilegais vinculados de alguma forma ao narcotráfico, começou em 2000, quando foi dada a partida no Plano Colômbia. Segundo as autoridades, nessa época foi possível reduzir à metade a área plantada, que, como se viu, havia alcançado o auge, com 163 mil hectares. Para conseguir esse resultado, com uma redução de 77 mil hectares, foi necessário fumigar 365 mil hectares. Em outras palavras, para tirar do mercado a produção de um hectare de coca é preciso fumigar cinco. As autoridades se orgulham também de ter diminuído a exportação de cocaína (440 toneladas) em cerca de 260 toneladas. O custo para os Estados Unidos foi alto: nesses anos foram investidos 3,3 bilhões de dólares, ou seja, metade da assistência militar destinada à região, e na Colômbia o orçamento do Ministério da Defesa teve um aumento de cerca de 3\% do PIB.

Alguns analistas assinalam que esses resultados não são compatíveis com o grande esforço feito. O pesquisador Darío Fajardo põe em dúvida os dados, e observa que mesmo o Relatório do UNDCP deixa de registrar uma redução no consumo e no número de consumidores. Comenta a evidência de que os cultivadores de coca estão compensando a redução da área plantada com o desenvol- 
vimento de uma nova variedade de árvore três vezes mais produtiva. Além disso, fazem plantações menores e as disfarçam em lugares onde a selva é mais densa, para que não sejam descobertas pelos sistemas de monitoração ${ }^{17}$.

Nos primeiros dois anos do "Plano Colômbia", quando Andrés Pastrana Arango era Presidente da República, não se tinha conseguido ainda articular uma estratégia coerente que respondesse efetivamente à mudança de visão do conflito colombiano ocorrida nos Estados Unidos. A fumigação foi intensificada, foram feitas ofensivas pontuais contra as guerrilhas e realizadas algumas ações contra os paramilitares e os pequenos cartéis da droga, mas não havia um plano geral orientado para uma mudança fundamental do conflito. Foi com a eleição e a posse do Presidente Uribe que se começou realmente a desenvolver um projeto com a mudança de objetivo, da contenção para a eliminação.

Gráfico 3 - Cultivos de papoula versus aspersão área de papoula

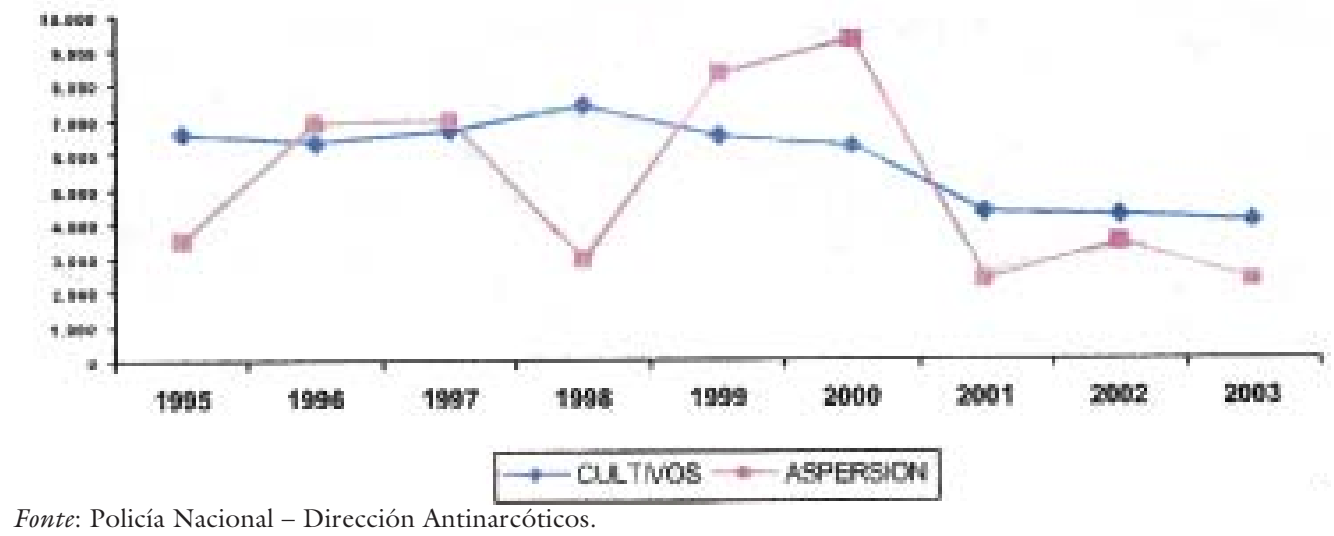

\section{Pacificação no Norte e guerra no Sul}

Não é um exagero dizer que o Presidente Uribe jogou uma pedra pesada nas águas represadas do debate nacional. Afirmou que a ameaça da insurgência tinha persistido porque nos últimos cinqüenta anos tinha faltado ao país uma liderança; porque os altos círculos da política e os intelectuais vinham contemporizando com as guerrilhas, se levar a sério a dura realidade representada pelos subversivos. Disse que na Colômbia não se pode falar de "conflito armado", mas sim de "ameaça terrorista"; que não se pode continuar dizendo que há uma guerra, porque não existem motivos para isso. Que a palavra "reconciliação" não tem cabimento na linguagem colombiana, porque não se deve aceitar que há uma fratura na sociedade.

Mas não se trata de uma mera mudança de conceitos, e sim de uma transformação drástica nas ações realizadas. Até há poucos anos ninguém pensaria que se pudesse entabular negociações políticas com os paramilitares, e Uribe abriu essa porta com tal rapidez e com tanta audácia que surpreendeu igualmente a comunidade internacional e opinião pública nacional. 
Os analistas tinham imposto ao país a idéia de que o conflito havia chegado a uma situação de "empate negativo", de um "impasse cômodo" no dizer de Richani, do qual era praticamente impossível sair a não ser por meio de uma negociação. Nem o Estado tinha condições de derrotar os guerrilheiros nem os insurgentes tinham condições de tomar Bogotá. Uribe rompeu essa simetria negativa, lançando-se com todas as forças para pôr contra a parede e dobrar a insurgência no Sul do país.

Por outro lado, Uribe afastou um certo pudor que os governantes colombianos ainda tinham com respeito à participação dos Estados Unidos no conflito, e aceitou facilmente a idéia que havia sido gerada nos círculos de Washington de que se devia passar da meta da contenção para o objetivo da eliminação. $O$ Presidente chamou de "segurança democrática" a sua estratégia, constante de duas linhas fundamentais: negociar com os paramilitares a sua desmobilização e derrotar militarmente as guerrilhas.

Esse modelo de segurança configurado no governo do Presidente Álvaro Uribe Vélez consistia na pacificação concertada no Norte do país e em guerra assistida pelos Estados Unidos no Sul, onde se encontra a retaguarda da guerrilha. É um projeto coerente, ousado e com grande apoio nacional e internacional. Mesmo assim, ele não conta com qualquer garantia de vitória, porque as raízes sociais do conflito, assentadas agora em centenas de milhares de camponeses produtores de coca, são muito profundas; porque nessa confrontação também interferem, de maneira decisiva, as atitudes dos opositores; porque os aliados jogam com cartas próprias; porque mesmo entre as forças do governo há ruídos e dissonâncias muitas vezes incontroláveis. A euforia que essa nova política provocou é uma parte importante da opinião pública, e não deixa ver os obstáculos e os seus gravíssimos custos humanitários.

\section{Uma negociação com muitas interrogações}

Há três anos os grupos paramilitares garantiam que só deixariam de atuar quando a guerrilha desaparecesse, e sobre a sua mudança de posição há várias interpretações. Os próprios dirigentes paramilitares justificam a sua decisão dizendo que agora temos um presidente com vontade de derrotar a guerrilha, e isso permite a sua desmobilização. No entanto, se fizemos uma análise mais profunda podemos chegar a conclusões diferentes. No fim do governo de Pastrana Arango os paramilitares demonstraram que, para derrotar a guerrilha, não eram tão eficientes. Eram bastante eficazes quando se tratava de pressionar a população civil nas regiões do conflito, nos massacres, nos deslocamentos forçados, e inclusive tinham tido bastante êxito no confronto com o ELN, que é uma força menos configurada como exército, mais miliciana; no entanto, no confronto direto com as Farc, sofreram grandes derrotas. Perante a comunidade internacional a ação paramilitar trouxe consigo um custo elevado em termos de legitimidade. E, algo ainda mais importante, os paramilitares chegaram ao máximo de acumulação de poder político, de influência social, de terras e capitais, em um 
trabalho ilegal ou semilegal, e era urgente encontrar uma base legal para consolidar esse seu grande poderio.

Não é difícil entender o raciocínio que foi feito por uma parte dos governantes do país. Havia chegado o momento de tentar recuperar o monopólio da contra-insurgência, com base no fortalecimento das Forças Armadas, da recuperação da legitimidade na comunidade internacional e da conquista, por esse meio, de um apoio político e militar decisivo nos Estados Unidos e na Europa. Se não tinha sido possível derrotar a insurgência com a ajuda dos paramilitares, e se eles tinham agora um vôo próprio, se não se podia esconder a sua vinculação com o narcotráfico, era obrigatório e urgente experimentar outro caminho.

Abriu-se assim a porta para a negociação, pensando-se talvez, em um primeiro momento, que a desmobilização poderia ser mais fácil e mais rápida. Quem criou esta ilusão foi o próprio Carlos Castaño, que chegou a conceber a negociação como uma "submissão à justiça"18. Chegou inclusive a dizer que essa submissão poderia significar a prisão nos Estados Unidos. Essa idéia tinha amadurecido em conversações não só com parte das suas próprias forças paramilitares, como também com amplos setores de puros narcotraficantes, que em algum momento lhe confiaram sua representação para falar diretamente com as autoridades norte-americanas, tal como foi revelado pela imprensa em 2000.

No entanto, Castaño desapareceu ou morreu em mãos dos seus próprios companheiros de armas, em ação que muitos interpretam como uma rebelião contra essa posição de "submissão à Justiça", e como afirmação da busca de uma negociação de caráter político, que tendesse tanto a evitar a extradição como a prisão dentro do país.

As conversações entre o governo e os paramilitares desandaram a partir de maio de 2004, quando desapareceu aquele que durante vários anos tinha sido o chefe máximo destes últimos. Depois disso a mesa de negociação passou a ser o cenário de disputas e acordos entre três posições distintas. De um lado, os Estados Unidos, cujo principal interesse era não desprezar a possibilidade de que os chefes paramilitares comprometidos com atividades do narcotráfico pudessem ser julgados em território americano. Sua idéia da negociação era, em essência, uma "submissão à Justiça". De outro lado, os paramilitares lutavam por atribuir um sentido puramente político a esses entendimentos. E o esquema do governo era uma mistura das duas opções: um pouco de negociação política e, até certo ponto, a "submissão à Justiça”.

Têm influência também na mesa de negociações a posição das organizações de direitos humanos e dos organismos internacionais, entidades que acolhem a voz das vítimas civis e que procuram fazer valer um mínimo de verdade, justiça e reparação. Elas têm um eco nessas conversações, débil mas difícil de ignorar.

O fato é que ainda hoje, no fim do ano de 2004, quando começou a desmobilização de alguns grupos paramilitares, não se sabe quais são os interesses que vão predominar. Um lugar importante para a resolução das tensões entre 
as diferentes posições é, sem dúvida, a aprovação da Lei da Verdade, Justiça e Reparação, mas sobre ela não há um consenso e a sua tramitação parlamentar ainda não começou. Portanto, persiste o clima de incerteza.

Incerteza que não é apenas jurídica, porque o tipo de negociação e o estilo da pacificação que vierem a ser feitas no Norte do país dependem da forma como se desenrole a guerra no Sul. A princípio, essa equação parecia muito fácil, e havia no governo a convicção de que o processo de desmobilização das Autodefesas poderia ocorrer simultaneamente com a derrota das Farc no Sul, mas em todo caso o triunfo sobre a guerrilha era mais importante e vinha em primeiro lugar, e não está claro que essa vitória esteja próxima. O Plano Patriota, que é, sem dúvida, a ofensiva mais ambiciosa que já se fez contra a guerrilha das Farc em toda a história, ainda não teve grandes resultados, e os guerrilheiros têm se defendido bastante bem ${ }^{19}$. Alguns analistas, como Alfredo Rangel, começam a dizer que nestas condições vai ser muito difícil para o governo promover um processo completo de desmobilização e de transferência das Autodefesas para a vida civil, já que elas podem preferir um acordo recíproco de desmobilização parcial e formas de cooperação especiais entre a força pública e os setores provenientes do paramilitarismo.

\section{$\mathrm{Na}$ defensiva mas longe da derrota}

O Presidente Uribe cumpriu, como nenhum dos seus antecessores, a promessa que fez de lançar uma ofensiva contra as guerrilhas para procurar derrotálas. Nesse esforço criou quatro novas brigadas móveis, quatro novos batalhões de alta montanha, cerca de seiscentos pelotões de soldados camponeses e admitiu uns quinze mil carabineiros. $\mathrm{O}$ aumento da força disponível para isso foi de oitenta mil homens ${ }^{20}$. Procurou igualmente reforçar o pessoal militar e os funcionários americanos posicionados em território colombiano, que chegou a duas mil pessoas - a maior delegação do mundo em um solo formalmente não ocupado. Aumentou ainda o orçamento colombiano da defesa, situando-o acima de cinco por cento do PIB, e conseguiu conservar uma assistência média da ordem de setecentos milhões de dólares por parte dos Estados Unidos.

Com essa mobilização de homens e recursos, o governo levou a força pública a mais de 150 municípios que estavam abandonados, conseguiu restabelecer o trânsito normal em algumas estradas e reduziu um pouco o número de homicídios e de seqüestros; o mais importante, porém, foi ter criado um ambiente de confiança e uma sensação de segurança que há algum tempo não havia no país.

A confrontação direta com a guerrilha tem ocorrido de duas formas: a primeira é a reação pronta aos seus ataques, com a mobilização de reforços e contra-ataques rápidos e decididos. Desta forma, aumentou o custo de qualquer operação de insurgência, e os movimentos de retirada tornaram-se particularmente penosos. A liberação do Bispo de Zipaquirá, seqüestrado pelas Farc, foi uma das primeiras surpresas da guerrilha devido a essa nova atitude tática do exército. A segunda forma consiste em concentrar uma força importante para 
lançar ofensivas sobre pontos-chave da guerrilha. Há três casos mais notáveis: a comuna 13 de Medelín, a Operação Liberdade no Departamento de Cundinamarca e a Operação Patriota, no Sul do país. As duas primeiras trouxeram um resultado favorável ao governo, com a reconquista de território e a perda de posições importantes pelos guerrilheiros. A terceira ainda está sendo executada, e é a prova de fogo que se faz na retaguarda estratégica das Farc.

As Farc e o ELN não só reconheceram nos seus documentos a posição ofensiva das forças militares como se posicionaram defensivamente, e nesta posição estão resistindo. O signo defensivo é visto na redução ocorrida dos seus ataques a instalações policiais e bases militares, da ordem de mais de $60 \%$. Em outras palavras, embora continuem a operar de forma tão intensa como na época de Pastrana, limitam-se a fustigar e atacar as forças governamentais que os cercam ou perseguem. Perderam cerca de $30 \%$ dos seus combatentes e tiveram algumas estruturas reduzidas ou dissolvidas; deixaram as zonas periféricas, onde tinham uma presença permanente, assim como algumas zonas de controle territorial, e chegaram a perder certos comandos médios e pessoas com grande influência política, como é o caso de Simon Trinidad. Suas fontes de recursos diminuíram. No entanto, é indiscutível que o núcleo das guerrilhas ainda não foi atingido. Suas estruturas de comando estão intactas e as regiões da retaguarda mais profunda ainda não foram vulneradas.

Alguns analistas, como Joaquín Villalobos ${ }^{21}$, já falam de uma “derrota estratégica" da guerrilha, esquecendo que na guerra é tão importante passar à ofensiva, quando as circunstâncias o justificam, como organizar a defensiva, quando as condições o exigem. Pode-se avaliar as forças que estão na ofensiva pela extensão dos danos causados ao inimigo, e as que estão na defensiva pelos danos que conseguem evitar, e pela sua capacidade de proteger-se. Mais ainda: se uma força militar em posição defensiva consegue chegar ao fim sem sofrer grandes perdas, obtém uma valiosa vitória relativa, e tem grandes possibilidades de organizar uma boa contra-ofensiva. Villalobos, que dirigiu a guerrilha do Fmln com um grande espírito ofensivo, e particularmente capaz nos ataques, não percebe que a grande arte das Farc está na defesa, na preservação - essa habilidade que lhes permitiu sobreviver durante quarenta anos, embora lhes tenha impedido aproximar-se efetivamente do triunfo.

Ninguém pode negar que o governo do Presidente Uribe fez um grande esforço ofensivo, apostando tudo na derrota da guerrilha; e é também indiscutível que conseguiu algumas vitórias. No entanto, pode-se afirmar que os resultados alcançados ainda não são proporcionais ao grande empenho havido na reorganização das forças governamentais, em homens e em recursos. Em todo caso, a disputa com as forças ilegais não terminou. O Plano Patriota tem seu objetivo traçado para meados de 2005. As definições orçamentárias para esse ano mostram que os recursos destinados à defesa aumentaram em pelo menos meio ponto porcentual do PIB; a força militar vai crescer com a formação de novas briga- 
das móveis, batalhões de alta montanha e pelotões de soldados camponeses. Isto significa que o esforço prosseguirá, e os próximos dois anos permitirão uma conclusão mais clara.

\section{O ataque às "zonas cinzentas"}

O principal equívoco da política de "Segurança Democrática" talvez seja o tratamento da população civil. O Presidente Uribe acredita que entre o Estado e a subversão existem importantes "zonas cinzentas". Crê que um grande número de organizações não governamentais, associações de camponeses e moradores, sindicatos, intelectuais e estudantes ou apóiam as guerrilhas ou adotam a seu respeito uma atitude complacente. A realidade, porém, é que esse vínculo entre a guerrilha e certos setores da sociedade, que na década de 1980 teve alguma importância, agora é quase inexistente. $\mathrm{O}$ conflito mudou radicalmente nos anos 1990. Com a queda do muro de Berlim e as transformações havidas no mundo, esfumou-se a ilusão de uma insurreição triunfante. Nesses anos, os ativistas sociais e políticos se afastaram da insurgência, e as guerrilhas se desenganaram completamente com a pouca resposta que as classes médias e os trabalhadores haviam dado ao apelo de um movimento armado. Atualmente, as guerrilhas se apóiam em setores marginais e ilegais da sociedade, nos jovens das favelas deprimidas economicamente, nos camponeses que cultivam coca, em todos os excluídos sociais. Mas esses marginais têm a dupla condição de ser vítimas e de fazer vítimas. Participam de atividades ilegais e atacam a sociedade, mas resumem a tragédia de uma nação que obriga milhões de pessoas a viver das migalhas de negócios sujos. São uma grande força social que ataca de fora do Estado e da sociedade formalmente estabelecida.

Pois bem, os dados sobre mortes, desaparecimentos e prisões publicados pelas próprias forças governamentais dão conta da enorme pressão aplicada aos civis e descrevem uma crise humanitária impressionante nestes dois anos de governo.

No balanço feito de dois anos de resultados da força pública, divulgados pelo Ministério de Defesa Nacional, aparecem estes números: 12.977 indivíduos capturados dos grupos subversivos, 3.841 mortos e 3.655 desertores, somando 20.473 pessoas $^{22}$. No entanto, dos capturados sobram apenas mil nos cárceres, $\mathrm{O}$ que sugere uma alta probabilidade de que os restantes nada tinham que ver com esses grupos subversivos. Com relação aos mortos, a situação é mais triste: as próprias guerrilhas mencionam 690 no caso das Farc e 170 no caso do ELN, o que estaria indicando que cerca de 2,8 mil desses mortos talvez fossem civis. O número dos presos por narcotráfico chega ao total de 97.670 , e não é preciso uma grande perspicácia para pensar que mais de noventa mil devem ser camponeses plantadores de coca.

Por outro lado, depois das violações do cessar fogo estabelecido pelas Autodefesas, a Comissão Colombiana de Juristas ${ }^{23}$ chegou ao número aterrorizante de 1.899 civis mortos ou desaparecidos em mãos das Autodefesas durante o período de negociação e de interrupção das hostilidades. 
Os seqüestrados e os prisioneiros de guerra ficaram presos no meio do cabo de guerra entre as Farc e o governo. Não foi possível promover o intercâmbio humanitário ${ }^{24}$ porque as duas partes não quiseram fazer a menor concessão política ou militar. Sempre que ocorre um mínimo de intercâmbio é porque uma pesquisa revela forte opinião favorável ou então porque surge um clamor da opinião pública ou da comunidade internacional. No entanto, logo que termina o eco do protesto as partes retornam ao seu mutismo.

\section{Diante de um provável fracasso}

As vozes possivelmente mais críticas à política norte-americana com relação à Colômbia e à região andina foram levantadas em Washington. O Council on Foreign Relations, um centro influente do pensamento americano, criou uma comissão independente que, em 2003, esteve na Colômbia, fazendo consultas com as fontes mais diversas, tendo publicado um relatório sobre a situação aconselhando uma mudança da política do governo dos Estados Unidos. Para essa comissão, a Colômbia é o país-chave da crise vivida pela região.

O Relatório diz claramente que a região caminha para o colapso, que a democracia está seriamente ameaçada e que a política do governo dos Estados Unidos é míope, sendo necessária uma mudança radical e urgente para deter a deterioração do quadro existente na região.

A política dos Estados Unidos nos Andes chegou a um ponto difícil. Ao longo dos últimos vinte anos foram gastos mais de 25 mil milhões de dólares nesse cenário, principalmente em uma guerra contra as drogas orientada para a erradicação e interceptação da oferta; mas esse esforço não se fez acompanhar de um interesse equivalente pelo desenvolvimento, o fortalecimento institucional e a implantação de reformas necessárias nos setores público e privado da região, bem como de uma estratégia integral e multilateral por parte dos países consumidores de drogas, para reduzir a sua demanda. É preciso urgentemente que os Estados Unidos, a comunidade internacional e os atores locais desenvolvam uma estratégia regional enérgica e integral que vá além das drogas e canalize recursos para um desenvolvimento amplo das zonas rurais e fronteiriças, assim como reformas judiciais e de segurança; e que mobilize o compromisso e o capital das elites locais, assim como recursos americanos e internacionais ${ }^{25}$.

O Relatório é minucioso e preciso nas suas recomendações. Poderíamos dizer que o seu enfoque é o de "dissolver o conflito". Ou seja: mantém a idéia de reprimir a produção, o tráfico e o consumo de drogas e os grupos armados que se sustentam na região, mas enfatiza a superação das causas econômicas e sociais que estão no fundo do conflito. "Dissolução do conflito", em lugar de "eliminação dos atores" seria uma forma de mostrar a diferença entre essa proposta e a atual política norte-americana. O ponto de partida é a consideração de que a Colômbia e, de modo geral, a região andina necessitam tanto de uma "assistência dura" como de "assistência branda", e critica fato de que a ajuda norte-americana se concentrou na primeira. Assinala como um sério erro o fato de que a 
ênfase da luta antidrogas se oriente para a oferta, e ataque principalmente o cultivo. Propõe que haja um equilíbrio entre os esforços destinados a combater o cultivo e o tráfico de drogas e, de outro lado, os recursos e esforços orientados para a redução do consumo. E também que a estratégia de ataques à oferta dê prioridade aos "níveis mais altos da indústria do narcotráfico, dos narcotraficantes e pequenos cartéis", deixando a fumigação como uma ação complementar e não predominante.

Indica claramente a necessidade de uma política especial do Fundo Monetário Internacional e do Banco Mundial, assim como dos países consumidores, para cooperar em larga escala com o desenvolvimento desses países; menciona a urgência de uma profunda reforma agrária e a importância de um Tratado de Livre Comércio com preferências e garantias para os países andinos.

Mostra que um ponto decisivo para apoiar as negociações é a paz na Colômbia e a obrigação de preparar para o pós-conflito.

A nova estratégia sugerida pelo Relatório do Council on Foreign Relations é sem dúvida mil vezes mais realista, inteligente e generosa do que a política hoje dominante em Washington, mas não questiona a base proibicionista da política norte-americana nem coloca no centro da superação do conflito um projeto de reconciliação nacional na Colômbia.

Por outro lado, é muito pouco provável que essa proposta seja acolhida em Washington. A reeleição de Bush deixa muito pouco espaço para recolocar a política norte-americana. O próprio Bush, ao passar pela Colômbia em novembro de 2004, confirmou a posição de dar continuidade ao Plano Colômbia e de financiar uma segunda fase a partir de 2005 , quando termina a primeira fase. $\mathrm{O}$ mais provável é que o conflito tenda a escalar e que o cultivo, processamento e tráfico de drogas se coloque mais ainda no centro dessa guerra. Na medida em que persistam os atores armados ilegais, que os camponeses plantadores de coca se radicalizem contra as fumigações, que o dinheiro continue fluindo para os narcotraficantes, e que os Estados da região andina mostram sinais de colapso, os Estados Unidos serão obrigados a aprofundar a sua intervenção, chegando inclusive a formas típicas de ocupação territorial, como aconteceu no Afeganistão, nosso irmão na desgraça das drogas, e que monopoliza o mercado da heroína.

A idéia de dissolver o conflito em vez de eliminar os seus atores, de atacar as causas fundamentais que o motivam e de considerar propostas de negociação é, sem dúvida, um caminho mais provável para a solução. No entanto, essa trajetória perde de vista algumas coisas. Assim, a guerrilha é anterior ao auge dos cultivos ilícitos; a colonização é anterior a eles, como a marginalização política e social de amplos setores camponeses e urbanos. Há na Colômbia um conflito com raízes históricas profundas. O que há vinte anos o Presidente Belisario Betancur chamou de "causas subjetivas", ou seja, a disposição e constância com que grupos de colombianos se levantaram em armas, na busca do seu reconhecimento e inclusão, tem um papel fundamental no conflito, e terá sem dúvida um 
papel principal na superação da guerra. Para falar com toda clareza, o caminho mais certo para por fim à guerra é a negociação política e a inclusão.

A reconciliação dos colombianos é o nome desse projeto. A negociação é central, não é lateral. Tentar a eliminação dos atores é a catástrofe. Tentar dissolver o conflito é uma política mais benévola e pode dar alguns resultados, mas o caminho da reconciliação é o que pode trazer melhor rendimento para a democracia, abreviando o tempo da confrontação.

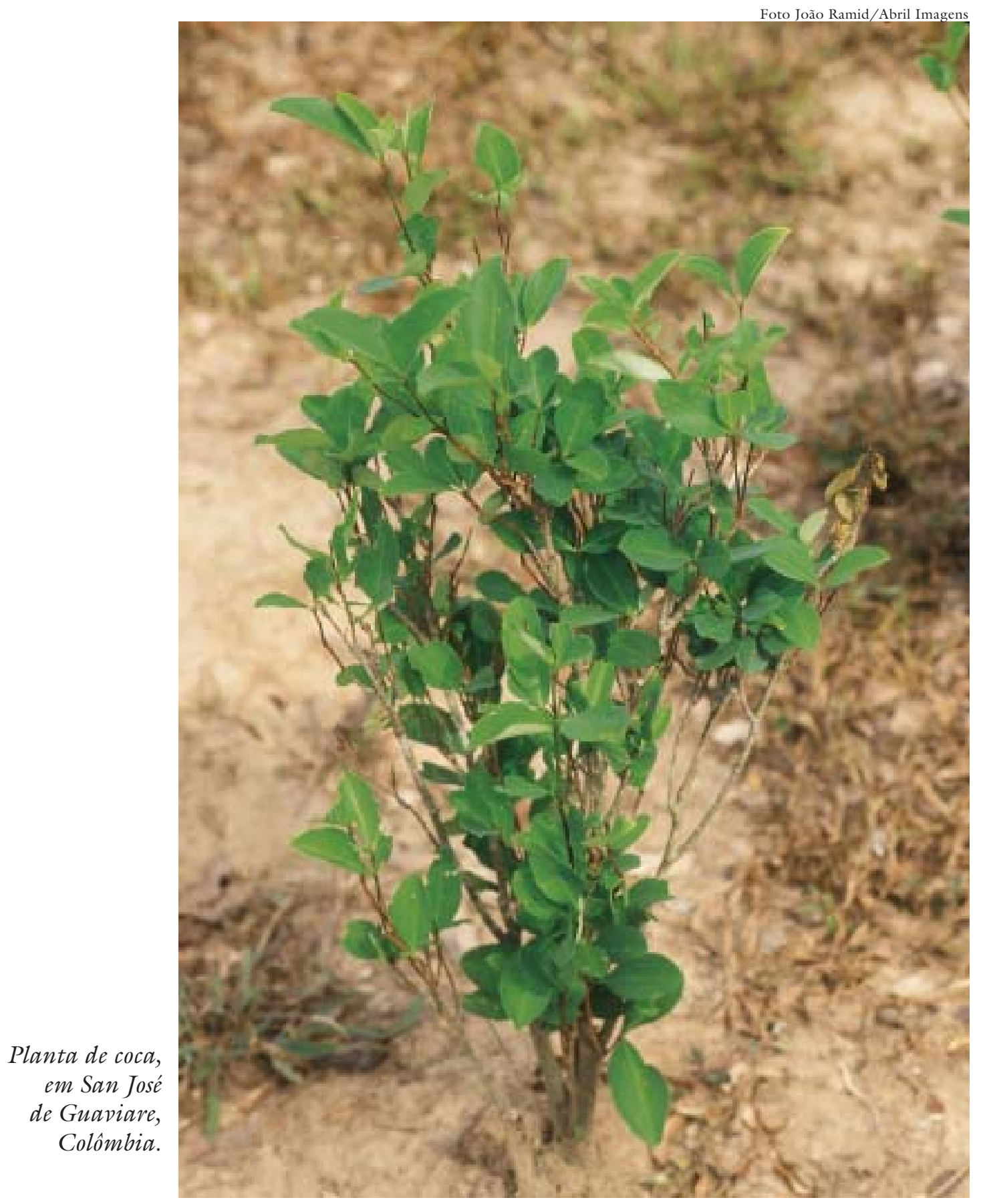

Estudos AvanÇAdOS 19 (55), 2005 
No entanto, a reconciliação implica explorar fórmulas como um governo de transição, do qual participem todos os atores do conflito. É buscar uma forma concertada de superar o cultivo, o processamento e o tráfico de drogas, oferecendo verdadeiros programas de desenvolvimento que gerem alternativas de vida distintas. É pôr em marcha um processo de reindustrialização do país e um projeto de reformas sociais profundas, tal como está sendo tentado no Sul do continente, sob a liderança do Presidente Lula. E é também atrever-se a procurar a flexibilização das políticas proibitivas das drogas, adotando formas persuasivas de reduzir o seu consumo.

Notas

I Entrevista para W emissora da Cadeia Caracol.

2 Relatório do Escritório de Crime e Drogas das Nações Unidas, 2004, Colombia Coca Cultivation Survey.

3 Álvaro Camacho Guizado e outros. Colombia: Violencia, democracia y derechos humanos. Editorial Tercer Mundo.

4 Nazih Richani, Sistemas de Guerra. La economía politica del conflicto en Colombia. Bogotá, Instituto de Estudos Políticos e Relações Internacionais (Iepri)/ Universidade Nacional da Colômbia, 2003.

5 Idem it.

6 Antonio Caballero, "Patadas de Ahorcado". Entrevista do jornalista Irragorri. Editorial Planeta, 2003.

7 Dados da Comissão Econômica para América Latina (Cepal).

8 Conversa do autor con Ricardo Avellaneda.

9 Carlos Castaño, Las autodefensas y la paz. Editorial Colombia Libre.

10 Ao longo do ano de 2003, as Autodefesas Unidas da Colômbia mantiveram entendimentos exploratórios com o Governo para chegar a um acordo visando à sua desmobilização e reinserção na vida civil. Desde julho de 2004, iniciaram um processo formal de negociações, e os seus principais dirigentes se instalaram em uma pequena vila do Departamento de Córdoba chamada Santa Fé Ralito.

11 Juan Camilo Restrepo, Coluna do jornal El Tiempo.

12 León Valencia, Adiós a la política, Bienvenida la Guerra. Intermedio Editores, 2002.

13 Los Costos de la Guerra. Programa Pela Paz da Companhia de Jesus, 2004.

14 Francisco Thoumi, El Imperio de la Droga. Narcotráfico, Economía y Sociedad en los Andes. Editorial Planeta, 2002.

15 Thoumi, op. cit.

16 UNDCP, op. cit.

17 Darío Fajardo, Conferência na Fundação Frederich Ebert. nov. 2004.

18 A figura da "submissão à Justiça" já foi utilizada na Colômbia em outras ocasiões para desarmar e desmobilizar grupos de narcotraficantes ou de paramilitares. Consiste em 
conceder benefícios penais, que podem chegar à liberdade condicional, em troca da decisão de abandonar o crime. Foi o que se fez em 1991 como parte da negociação com dois pequenos grupos paramilitares: um no Departamento de Córdoba, o outro na região do médio Magdalena. Por outro lado, a negociação política tem sido utilizada muitas vezes na Colômbia em busca de acordos de paz com as guerrilhas. Nessas negociações o objetivo é vincular à vida democrática grupos políticos que se levantaram em armas contra o Estado. As figuras jurídicas utilizadas no quadro dessas negociações políticas são as do indulto e da anistia.

19 "Plano Patriota" é o nome dado a uma grande ofensiva militar contra a retaguarda das Farc, mobilizando dezessete mil soldados, com importante apoio aéreo, tendo por objetivo derrotar a guerrilha nos Departamentos de Meta, Caquetá, Putumayo e Guaviare.

20 Relatório da Fundação Segurança e Democracia, organização não governamental dirigida por Alfredo Rangel, que até pouco tempo atrás foi um assessor do Ministério da Defesa.

21 Joaquín Villalobos foi o principal comandante da Fmln de El Salvador. Depois dos acordos de paz dedicou-se à análise de temas de segurança e a assessorar os governos em vários países.

22 Ministerio de Defensa Nacional de Colombia. Viceministerio de Gestión Institucional. Resultados de la Fuerza Pública contra la violencia, criminalidad y terrorismo. Balance de 24 meses del gobierno del presidente Uribe.

23 Comisión Colombiana de Juristas. Relatório dessa organização não governamental baseado em informações colhidas em diversos jornais nacionais e regionais, assim como nas denúncias de vítimas, apresentadas a organismos de defesa dos direitos humanos.

$24 \mathrm{O}$ "Intercâmbio Humanitário" é uma figura que se tem utilizado para designar uma possível negociação entre as Farc e o Governo nacional, orientada para liberar os seqüestrados e prisioneiros de guerra da guerrilha, como também os guerrilheiros presos pelas forças governamentais.

25 Andes 2020. Una nueva estrategia ante los retos que enfrentan Colombia y la región andina. Bogotá, Fundação Friedrich Ebert Stiftung/ Council On Foreign Relations, 2004.

León Valencia é colunista dos jornais El Tiempo e El Colombiano.

@ - Imgil@nuevoarcoiris.org.co

Tradução de Sérgio Bath. Publicado originalmente em português na revista DEP-Diplomacia, Estratégia e Política, vol. 1, n. 2, jan. 2005, pp. 78-104.

Recebido em 11.8.05 e aceito em 30.8.05. 